\title{
An Investigation by Autoradiography and Electron Microscopy of the Localization of Prenols in Lactobacillus casei
}

\author{
By KAREEN J. I. THORNE, L. S. SWALES AND D. C. BARKER* \\ Dunn Nutritional Laboratory, University of Cambridge, and \\ Medical Research Council, Cambridge
}

(Received I8 July I973, revised I4 September 1973)

\begin{abstract}
SUMMARY
The localization of total and newly synthesized $\left[{ }^{3} \mathrm{H}\right]$ prenol in Lactobacillus casei was investigated by autoradiography of electron micrographs of bacteria grown with $\left[{ }^{3} \mathrm{H}\right]$ mevalonic acid. The distribution of radioactive grains differed from a random distribution in being concentrated in the membrane; this confirmed earlier chemical studies. The distribution of total $\left[{ }^{3} \mathrm{H}\right]$ prenol along the cell, after continuous growth with $\left[{ }^{3} \mathrm{H}\right]$ mevalonic acid, did not indicate any specific localization. Newly synthesized prenol, located after a 20 min pulse with $\left[{ }^{3} \mathrm{H}\right]$ mevalonic acid, was also uniformly distributed except in organisms which had spent the previous $20 \mathrm{~min}$ forming septa. In these bacteria there was a concentration of prenol in the septal region.
\end{abstract}

\section{INTRODUCTION}

Mevalonic acid is incorporated by Lactobacillus casei predominantly into $\mathrm{C}_{55}$ prenol (Thorne \& Kodicek, I966), a lipid carrier concerned with cell-wall biosynthesis (Higashi, Strominger \& Sweeley, 1967; Wright, Dankert, Fennessey \& Robbins, 1967; Troy, Frerman \& Heath, 1971; Hussey \& Baddiley, 1972; Hancock \& Baddiley, 1972). This prenol is located in both the mesosome and plasma membranes of the cell at a concentration of $2.5 \mu \mathrm{g} / \mathrm{mg}$ protein (Thorne \& Barker, 1972). The distribution of total and newly synthesized prenol along the cell has now been investigated by autoradiography of electron micrographs of $L$. casei grown with $\left[{ }^{3} \mathrm{H}\right]$ mevalonic acid.

\section{METHODS}

Growt of bacteria. Lactobacillus casei (ATCC 7469) was grown for $\mathrm{I} 6 \mathrm{~h}$ at $37^{\circ} \mathrm{C}$, to a density of about $0.8 \mathrm{mg}$ dry wt $/ \mathrm{ml}$, in Io $\mathrm{ml}$ of acetate-free medium (Thorne \& Kodicek, I962). For continuous labelling $7 \mu \mathrm{Ci}(\mathrm{I} \cdot 4 \mathrm{nmol})$ of $\left[2^{-3} \mathrm{H}\right]$ mevalonic acid (Radiochemical Centre, Amersham, Buckinghamshire) was included in the growth medium throughout the growth period. For pulse labelling the same amount of $\left[2-{ }^{3} \mathrm{H}\right]$ mevalonic acid was added, but only for the last $20 \mathrm{~min}$ of growth. Cultures were harvested by centrifuging at $1500 \mathrm{~g}$ for $5 \mathrm{~min}$, washed once with $0.9 \%(\mathrm{w} / \mathrm{v})$ saline and incubated for $5 \mathrm{~min}$ with non-radioactive growth medium. This final incubation with growth medium was included because fixation of bacteria for electron microscopy was most successful when osmium tetroxide was added directly to growing cultures (Barker \& Thorne, 1970) and to reduce contamination by free, unmetabolized $\left[{ }^{3} \mathrm{H}\right]$ mevalonic acid.

Electron microscopy and autoradiography. Bacterial samples were fixed, stained, dehydrated and embedded as described previously (Barker \& Thorne, I970). Silver sections were cut on

\footnotetext{
* Present address: MRC Unit for Biochemical Parasitology, Molteno Institute, University of Cambridge,
} Cambridge, CB 23 EE. 
an OMU-2 Reichert ultramicrotome using a diamond knife. Sections were mounted on collodion-coated 200-mesh nickel or gold grids and coated with a $5 \mathrm{~nm}$ layer of carbon. The grids were then mounted on to corks using double-sided Scotch tape, and covered with a monolayer of gelled Ilford $\mathrm{L}_{4}$ emulsion using a $3 \mathrm{~cm}$ platinum loop (Caro \& van Tubergen, 1962). Corks were then inserted into perforated plastic tubing and placed in light-tight boxes with a drying agent and $\mathrm{CO}_{2}$ atmosphere. Exposure took place at $4{ }^{\circ} \mathrm{C}$ for 6 months. Samples were developed at $20{ }^{\circ} \mathrm{C}$, in Kodak Di9 for $4 \mathrm{~min}, \mathrm{r} \%$ acetic acid for I min, $20 \%$ sodium thiosulphate for $4 \mathrm{~min}$, and finally washed with water for $\mathrm{I}$ o min. Electron micrographs obtained with an AEI EM6B microscope at a magnification of $\times 5500$. For statistical analysis, micrographs were enlarged to $\times 30000$.

Localization of prenol in the cell. A circle was drawn round each silver grain, the centre being the mid-point of the longest axis. The circle was chosen to have a diameter of $7.5 \mathrm{~mm}$, equivalent to the resolution of the autoradiographic system (Bachmann \& Salpeter, 1965; Salpeter, Bachmann \& Salpeter, 1969). The potential isotope sources within this circle were noted. The bacterial cell was divided into items and compound items which were selected to include all ultrastructurally identifiable features of interest. To measure the effective area and organization of the potential isotope sources a transparent screen with circles equivalent in size to the silver grains was superimposed on each autoradiogram. The distribution of the circles related to items was compared with that of authentic grains over items by applying $\chi^{2}$ to check for a random or non-random grain distribution (Williams, I969).

Localization of prenol along the cell. Evidence for an uneven distribution of prenol between septa, side walls and polar caps of the bacteria was looked for. A circle of diameter $7.5 \mathrm{~mm}$ was drawn round each silver grain, the centre being the mid-point of the longest axis. Only circles which made contact with the cell envelope were counted. Cell envelopes were divided into three items: polar caps, side walls and septa. The divisions were such that an equal length of envelope was included in each item with the exception of the newly forming septa (see Fig. 2, below). The length of membrane in all other bacteria was measured by a mapmeasurer and the divisions arranged so that in each organism the lengths of envelope in the polar cap, side wall and septa were in the ratio of $I: I: I$ per half cell. By this method of division we avoided any variation in the lengths of the sides. We realize that the items selected in this way give us only a first-order approximation as no account has been taken of the cross-grain effects of the radius of curvature of the polar caps. The actual ratio will not be exactly $\mathrm{I}: \mathrm{I}$ : I but we felt that the discrimination of the method did not justify submitting every autoradiogram to seriological examination using random lines. As only longitudinally sectioned bacteria, greater than $2 \cdot 2 \mathrm{~cm}$ in width and $3 \mathrm{~cm}$ in length, were used the simple geometric measurement gives us a satisfactory comparison. Since each class contained equal lengths of membrane, evenly distributed grains would also be equally distributed between the three classes. An unequal distribution would imply localization of the prenol in discrete regions of the cell. In general the methods of Williams (I973) have been followed.

\section{Localization of prenol in the cell}

\section{RESULTS}

The distribution of radioactive and of random material, after continuous labelling and after a 20 min pulse of radioactive mevalonic acid, is shown in Table I. The ultrastructural features which could be distinguished under the silver grains were cytoplasm, DNA, cell envelope and septum. The envelope included both membrane and wall as the size of the grains was too large for separate designation (see Fig. I). Mesosomes could not be seen by 
Table I. Localization of $\left[{ }^{3} \mathrm{H}\right]$ prenol in bacterial cell

Continuously labelled cells

$\begin{array}{ccc}\begin{array}{c}\text { Radioactive } \\ \text { grains } \\ (\%)\end{array} & \begin{array}{c}\text { Random } \\ \text { circles } \\ \%\end{array} & \frac{\text { Radioactive }}{\text { Random }}\end{array}$

Cytoplasm

Cytoplasm/DNA

Cytoplasm/envelope

Cytoplasm/envelope/ outside

Envelope/outside

Cytoplasm/septum

Cytoplasm/envelope/ septum

Cytoplasm/envelope/ septum/outside

Envelope/septum/ outside
Twenty min pulse labelled cells

\begin{tabular}{|c|c|c|}
\hline $\begin{array}{c}\text { Radioactive } \\
\text { grains } \\
(\%)\end{array}$ & $\begin{array}{l}\text { Random } \\
\text { circles } \\
(\%)\end{array}$ & $\frac{\text { Radioactive }}{\text { Random }}$ \\
\hline $16 \cdot 37$ & $20 \cdot 28$ & 0.81 \\
\hline $5 \cdot 75$ & $7 \cdot 25$ & 0.79 \\
\hline $22 \cdot 12$ & 10.08 & $2 \cdot 19$ \\
\hline 33.42 & $36 \cdot 33$ & 0.92 \\
\hline 16.59 & $22 \cdot 93$ & 0.72 \\
\hline $2 \cdot 43$ & I'54 & $I \cdot 58$ \\
\hline $\mathrm{I} \cdot 77$ & 0.43 & $4 \cdot 12$ \\
\hline $\mathbf{I} \cdot \mathbf{I} \mathbf{I}$ & 0.98 & $I \cdot I 3$ \\
\hline 0.44 & 0.18 & $2 \cdot 44$ \\
\hline
\end{tabular}

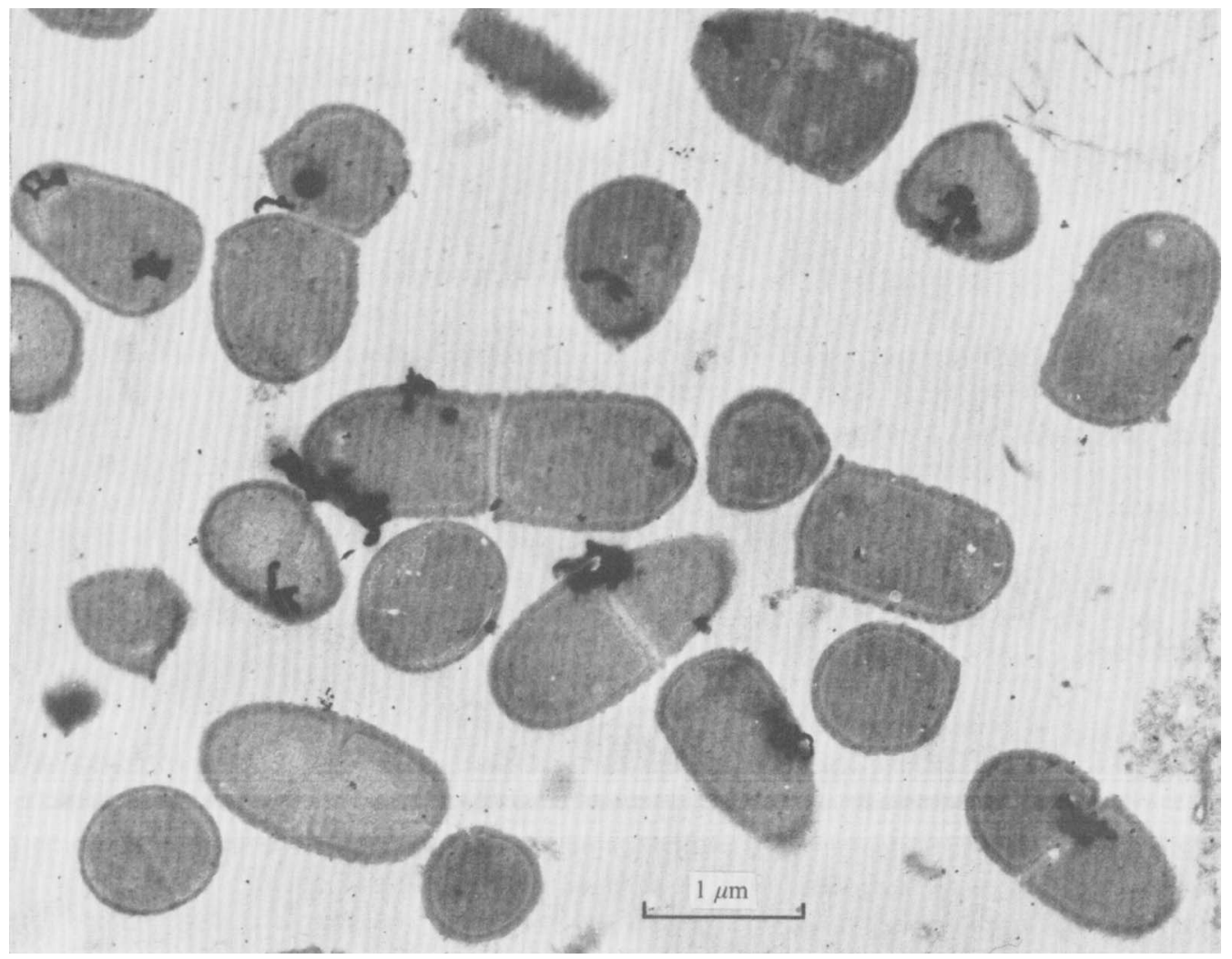

Fig. I. Autoradiogram of $L$. casei grown with $\left[2-{ }^{3} \mathrm{H}\right]$ mevalonic acid. 
(a)

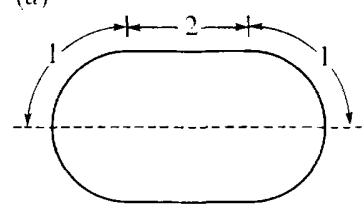

(c)

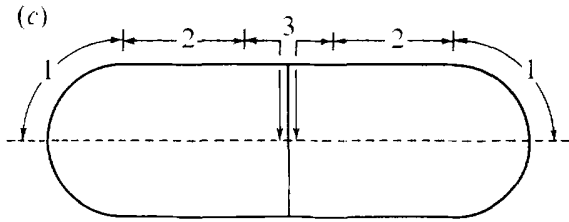

(b)

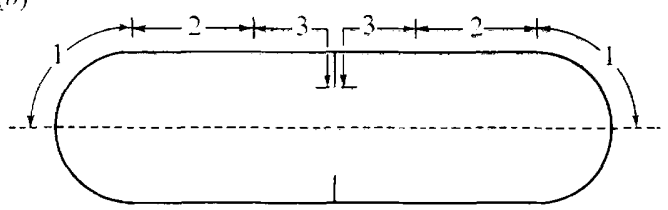

(d)

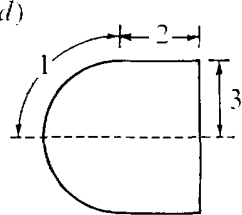

Fig. 2. Diagram of cells at different stages of cell cycle. (a) Separate symmetric cells; $(b)$ cells with partial septum; $(c)$ cells with complete septum; $(d)$ separate asymmetric cells. Lengths $\mathbf{I}=2=3$.

Table 2. Relative concentration of $\left[{ }^{3} \mathrm{H}\right]$ prenol in different regions of the bacterial cell

Cell item

Outside/envelope

Outside/envelope/cytoplasm

Envelope/cytoplasm

Cytoplasm

\section{Relative concn \\ $\left[{ }^{3} \mathrm{H}\right]$ prenol}

0.67

I.03

I. 89

$0 \cdot 74$

this method as overlying silver grains obscured them. In the continuously labelled cells a total of I 66 radioactive grains and I 300 random circles, and in the pulse labelled cells 452 radioactive grains and 1627 random circles, were counted. In both experiments the location of the radioactive grains differed significantly from a random distribution ( $\chi^{2}$ test, $P<2 \%$ ). The cell items with the highest concentration of radioactivity, as compared with their random occurrence, were those containing cell envelope and septal regions. The results are shown in Table 2. It is evident that the concentration of $\left[{ }^{3} \mathrm{H}\right]$ prenol is greatest in the envelope/ cytoplasm item and falls away towards the cytoplasm and towards the outside. This locates the prenol on the cytoplasm side of the envelope, or in the membrane, confirming earlier chemical studies (Barker \& Thorne, 1970; Thorne \& Barker, 1972). Similar considerations place prenol in the septal membrane.

\section{Localization of prenol along the cell}

To discover if there was any preferential site for prenol occurrence or for prenol synthesis along the bacterium, the bacteria were divided into four groups: (a) separate, symmetric bacteria; $(b)$ bacteria with a partial septum; $(c)$ bacteria with a complete septum; $(d)$ separate, asymmetric bacteria where new, septal wall is still recognizable (Fig. 2). The bacteria were not growing in chains. A total of 509 radioactive grains was counted in bacteria from continuously labelled cultures and 332 in bacteria from pulse labelled cultures.

The results are shown in Table 3. The site of total prenol was obtained from continuously labelled cells and of prenol synthesized during the previous $20 \mathrm{~min}$ from pulse labelled cells. In $(a)$ the presence of two indistinguishable polar ends means at a first approximation that twice as much membrane is present at the ends of the cell as at the side. An even distribution of prenol would therefore be $66.7 \%$ at the ends and $33.3 \%$ at the sides of the cell. This was 
Table 3. Distribution of radioactive prenol along the cell

\begin{tabular}{|c|c|c|c|c|c|c|}
\hline \multirow{3}{*}{ (a) } & \multirow{2}{*}{ Separate cells, symmetric } & \multirow{2}{*}{$\begin{array}{c}\text { Cell } \\
\text { length } \\
(\%)\end{array}$} & \multicolumn{2}{|c|}{ Continuous label } & \multicolumn{2}{|c|}{20 min pulse } \\
\hline & & & Grains & $\%$ & Grains & $\%$ \\
\hline & $\begin{array}{l}\text { Separate cells, symmetric } \\
\text { I end }\end{array}$ & $66 \cdot 7$ & 76 & $6 I \cdot 3$ & 37 & $62 \cdot 8$ \\
\hline & 2 side & $33 \cdot 3$ & 48 & $38 \cdot 7$ & 22 & $37 \cdot 2$ \\
\hline (b) & Partial septum & & & & & \\
\hline & I polar end & $33 \cdot 3$ & 24 & $42 \cdot 2$ & 25 & $36 \cdot 8$ \\
\hline & 2 side & $33 \cdot 3$ & 15 & $26 \cdot 3$ & 24 & $35 \cdot 3$ \\
\hline & 3 septum & $33 \cdot 3$ & 18 & $3 I \cdot 5$ & 19 & $27 \cdot 9$ \\
\hline (c) & Complete septum & & & & & \\
\hline & I polar end & $33 \cdot 3$ & 74 & $33 \cdot 2$ & 38 & $35 \cdot 2$ \\
\hline & 2 side & $33 \cdot 3$ & 65 & $29 \cdot I$ & 33 & $30 \cdot 5$ \\
\hline & 3 septum & $33 \cdot 3$ & 84 & $37 \cdot 7$ & 37 & $34 \cdot 3$ \\
\hline (d) & Separated cells, asymmetric & & & & & \\
\hline & I polar end & $33 \cdot 3$ & 42 & $40 \cdot 0$ & 20 & $20 \cdot 6$ \\
\hline & 2 side & $33 \cdot 3$ & 27 & $25 \cdot 7$ & 34 & $35 \cdot I$ \\
\hline & 3 septal end & $33 \cdot 3$ & 36 & $34 \cdot 3$ & 43 & $44 \cdot 3$ \\
\hline
\end{tabular}

Table 4. Distribution of radioactive prenol between cells at different stages of the cell cycle

(a) Separate cells, symmetric

$\begin{array}{cc}\text { Grains } & \% \text { of total } \\ \text { I } 24 & 24.4 \\ 57 & \text { I I.2 } \\ 223 & 43 \cdot 8 \\ \text { I05 } & 20 \cdot 6\end{array}$

\begin{tabular}{|c|c|}
\hline \multicolumn{2}{|c|}{$20 \mathrm{~min}$ pulse } \\
\hline Grains & $\%$ of total \\
\hline $\begin{array}{l}59 \\
68\end{array}$ & $\begin{array}{l}17 \cdot 8 \\
20 \cdot 2\end{array}$ \\
\hline 108 & $32 \cdot 7$ \\
\hline 97 & $29 \cdot 3$ \\
\hline
\end{tabular}

\begin{tabular}{c}
20 min pulse \\
\hline $\begin{array}{c}\text { Continuous } \\
\text { label }\end{array}$ \\
0.73 \\
$\mathrm{I} \cdot 80$ \\
0.75 \\
$\mathrm{I} \cdot 42$
\end{tabular}

observed in both experiments. In all the other groups an even distribution would be represented, again at a first approximation, by one-third in each region of the bacterium. In none of the continuously labelled cells did the distribution of prenol differ significantly from this. Specific localization of newly formed prenol was found only in newly separated bacteria, in group $(d)\left(\chi^{2}\right.$ test, $\left.2 \%>P>\mathrm{I} \%\right)$. Here most activity was found at the septal end and least at the polar end. It appears that during the previous $20 \mathrm{~min}$, while the septum formed and the cells separated, prenol synthesis was somewhat more active in the region of newly forming septum. The mean generation time of these cells was $2 \mathrm{~h}$. At all other stages of the growth cycle prenol synthesis occurred along the whole length of the cell, including the polar ends.

Prenol synthesis at different stages of the growth cycle

A significant difference in distribution between newly synthesized prenol and total prenol in cells at different stages of the growth cycle was observed (Table $4, P<\mathrm{I} \%$ ). Most active synthesis, compared to total level, was found in cells $(b)$ with a partial septum, and in newly separated cells $(d)$. It is possible that during the previous 20 min cells $(b)$ had maximal lengthening activity while cells $(d)$ were forming a septum.

\section{DISCUSSION}

At the discrimination provided by the method, i.e. the operational ability to localize the source of a grain, the level of total prenol is constant along the length of the cell, giving a potential capacity for wall synthesis at all sites. The discrete sites of wall synthesis suggested 
by the work of Hughes \& Stokes (I97I) with Bacillus licheniformis, Briles \& Tomasz (1970) with Diplococcus pneumoniae, Higgins \& Shockman (1970) with Streptococcus faecalis and Ryter (I973) with Escherichia coli are therefore probably not controlled by a local high concentration of prenol.

The rate of prenol synthesis was not constant during the cell cycle. It is possible that the times when prenol synthesis was most active correspond to periods of increased elongation activity and septum formation. After the latter the newly synthesized prenol was concentrated in the septal region, indicating that septal membrane was synthesized specifically at this site and did not flow in by a general expansion of membrane growing all over the cell. Conversely, prenol synthesis associated with the growing cell occurred equally at all sites. This resembles the even distribution of newly synthesized membrane phospholipid observed in E. coli (Lin, Hirota \& Jacob, 1971 ; Green \& Schaechter, 1972). Morrison \& Morowitz (I970), however, found that new phospholipid is synthesized in the first $0.2 \mu \mathrm{m}$ of the cell in Bacillus megaterium. This could be septal membrane.

We are grateful to Dr E. Kodicek for his interest and advice, and thank Mr K. C. Day for his skilful technical assistance.

\section{REFERENCES}

Bachmann, L. \& Salpeter, M. N. (1965). Autoradiography with the electron microscope. A quantitative evaluation. Laboratory Investigation I4, I04 I-I053.

BARKer, D. C. \& Thorne, K. J. I. (1970). Spheroplasts of Lactobacillus casei and the cellular distribution of bactoprenol. Journal of Cell Science $7,755-785$.

Briles, G. B. \& Tomasz, A. (I970). Radioautographic evidence for equatorial wall growth in a Gram-positive bacterium. Journal of Cell Biology 47, 786-790.

Caro, L. G. \& van Tubergen, R. P. (1962). High resolution autoradiography. Journal of Cell Biology $\mathbf{5}$, I73-I99.

Green, E. W. \& Schaechter, M. (1972). The mode of segregation of the bacterial cell membrane. Proceedings of the National Academy of Sciences of the United States of America 69, 2312-23 I6.

HANCOCK, I. C. \& BADDILEY, J. (1972). Biosynthesis of the wall teichoic acid in Bacillus licheniformis. Biochemical Journal 127, 27-37.

Higashi, Y., Strominger, J. L. \& Sweeley, C. C. (1967). Structure of a lipid intermediate in cell-wall peptidoglycan synthesis: a derivative of $\mathrm{a} \mathrm{C}_{55}$ isoprenoid alcohol. Proceedings of the National Academy of Sciences of the United States of America 57, 1878-1884.

Higgins, M. L. \& Shockman, G. D. (I970). Model for cell-wall growth of Streptococcus faecalis. Journal of Bacteriology Ior, 643-648.

Hughes, R. C. \& STOKES, E. (1971). Cell-wall growth in Bacillus licheniformis followed by immunofluorescence with mucopeptide-specific antiserum. Journal of Bacteriology 106, 694-696.

Hussey, H. \& BADDILEY, J. (1972). Lipid intermediates in the biosynthesis of the wall teichoic acid in Staphylococcus lactis I3. Biochemical Journal 127, 39-50.

Lin, E. G. C., Hirota, Y. \& JACOB, F. (I97I). On the process of cell division in Escherichia coli. VI. Use of a methocel-autoradiographic method for the study of cellular division in Escherichia coli. Journal of Bacteriology 108, 375-385.

Morrison, D. C. \& MorowitZ, H. J. (1970). Studies on membrane synthesis in Bacillus megaterium KM. Journal of Molecular Biology 49, 44I-459.

RYter, A. (1973). Generation of subcellular structure. Proceedings of the First John Innes Symposium.

Salpeter, M. M., BachmanN, L. \& Salpeter, E. E. (1969). Resolution in electron microscope autoradiography. Journal of Cell Biology 4r, I-20.

Thorne, K. J. I. \& BARKer, D. C. (1972). The occurrence of bactoprenol in the mesosome and plasma membranes of Lactobacillus casei and Lactobacillus plantarum. Journal of General Microbiology 70, 87-98.

Thorne, K. J. I. \& Kodicex, E. (1962). The metabolism of acetate and mevalonic acid by lactobacilli. I. The effect of acetate and mevalonic acid on growth. Biochimica et biophysica acta 59, 273-279. 
THORNe, K. J. I. \& KodiceK, E. (1966). The structure of bactoprenol, a lipid formed by lactobacilli from mevalonic acid. Biochemical Journal 99, I $23-\mathrm{I} 27$.

Troy, F. A., Freerman, F. E. \& Heath, E. C. (197I). The biosynthesis of capsular polysaccharides in Aerobacter aerogenes. Journal of Biological Chemistry 244, 4406-4412.

Williams, M. A. (1969). The assessment of electron microscope autoradiographs. In Advances in Optical and Electron Microscopy, vol. 3. Edited by R. Barer and V. E. Cosslett. New York: Academic Press.

Williams, M. A. (1973). Electron microscope autoradiography. In Techniques in Protein Biosynthesis, vol. 3. Edited by P. M. Campbell and D. R. Sargent. New York: Academic Press.

Wright, A., Dankert, M., Fennessey, P. \& Robiins, P. W. (1967). Characterisation of a polyisoprenoid compound functional in $O$-antigen biosynthesis. Proceedings of the National Academy of Sciences of the United States of America 57, 1798-1803. 